\title{
A Study on the Adaptability of Person Deixis in English Teacher Talk*
}

\author{
XI Hong-mei, LIU Dan, WANG Dan-yu \\ Harbin Engineering University, Harbin, China
}

\begin{abstract}
Teacher talk is an influential factor for conducting English class effectively. The use of person deixis in teacher talk has an important effect on classroom interaction and students' language learning. This paper, based on Jef Verschueren's Adaptation Theory, mainly explores the adaptability of person deixis in English teacher talk in the communicative classroom context. The study shows the employment of person deixis in English teacher talk is not arbitrary, but adapts to the communicative contextual factors, i.e., adapts to emotive elements, like empathy, face, motivation, etc., adapts to the social relations between teachers and students, and the teachers' roles, and adapts to the students' physical feedback, etc. Conducting research on person deixis in teacher talk is conducive to understanding the dynamic process of language use.
\end{abstract}

Keywords: person deixis, teacher talk, adaptability

\section{Introduction}

English teaching not only aims to improve students' English linguistic competence, but also to enhance students' pragmatic competence. To some extent, teacher talk is an important means of English input to students and it also plays a crucial role in establishing beneficial relations between teachers and students, which may promote students' learning effects. Therefore, much more attention has been drawn to this field in recent decades. In actual English teaching, teachers consciously or unconsciously employ deixis in their talks, which has been a universal linguistic phenomenon, that is, all human languages contain deictic terms (Huang, 2009).

Deictic systems in natural languages are not arbitrarily organized around the features of just any of the many different kinds of medium and context in which languages are used. Rather there is an essential assumption of that basic face-to-face conversational context in which all humans acquire language (Lyons, 1977; Levinson, 1983). Jef Verschueren's Adaptation Theory brings a new perspective to language production and interpretation and sheds light on the dynamic process of language use. This paper will adopt the Adaptation Theory to analyze the adaptability of person deixis in English teacher talk and try to interpret how they adapt to the mental world, the social world, and the physical world of communicative context, thus satisfying communicative needs. Also,

\footnotetext{
* Acknowledgements: This paper was funded by Heilongjiang Provincial Higher Education Project (16G033), Fundamental Research Funds for the Central Universities (HEUCF161209), and HEU Teaching Reform Project (JG2016BZD29).

XI Hong-mei, professor, master, Foreign Languages Department, Harbin Engineering University.

LIU Dan, lecturer, master, Foreign Languages Department, Harbin Engineering University.

WANG Dan-yu, lecturer, master, Foreign Languages Department, Harbin Engineering University.
} 
another purpose is to offer further interpretation to the idea that proper use of person deixis in teacher talk would enhance English language learning and teaching effects.

\section{A General Study on Person Deixis}

The term "deixis" is derived from the Greek word meaning "to show" or "to point out". Deixis is directly concerned with the relationship between the structure of a language and the context in which the language is used (Huang, 2009). Person deixis concerns the encoding of the role of participants in the speech event in which the utterance in question is delivered: The category first person is the grammaticalization of the speaker's reference to himself, second person the encoding of the speaker's reference to one or more addressees, and third person the encoding of reference to persons and entities which are neither speakers nor addressees of the utterance in question (Levinson, 1983). Person deixis is mainly realized by personal pronouns. Two dimensions of distinction are common: one based on the distinction of participant roles, like the speaker "I" and "we" and the hearer "you", and the other based on the distinction of number, like the singular "I" and the plural "we" (Chen, 2009). But in the actual communicative context, deictic expressions or deictics can be used both deictically and non-deictically. For instance:

Example (1) Teacher to students: You and you, but not you, go back to your seats. (a deictic usage)

Example (2) Teacher to students: You can't have everything in this life. (a non-deictic usage)

Within deictic use, a further distinction can be drawn between gestural and symbolic use (Fillmore, 1971). Gestural use can be properly interpreted only by a direct, moment by moment monitoring of some physical aspects of the speech event. By contrast, interpretation of the symbolic use of deictic expressions only involves knowing the basic spatio-temporal parameter of the speech event. In Example (1), "you" is a gestural use. In Example (2), "you" is used as impersonal, similar in function to "everyone"; in other words, it is used non-deictically.

There are other complications. For instance:

Example (3) Teacher to students: We'll have a break after the presentation.

Example (4) Teacher to students: Can we stop talking?

Example (5) Teacher to students: We have the responsibility to educate you.

Given the communicative context, "we" can be used in the following three ways: we-inclusive-of-addresser/addressee in Example (3); we-exclusive-of-addresser in Example (4); and we-exclusive-of-addressee in Example (5). From the above examples, we can see that the correct reference of the person deixis depends on context. Taking context into account, we may interpret and understand the reference of the person deixis. In other words, the real meaning of the person deixis may be achieved from the perspective of pragmatics.

\section{Verschueren's Adaptation Theory}

Adaptation Theory was first proposed by Jef Verschueren in Pragmatics as a Theory of Linguistics Adaptation in 1987, then he published a new book Understanding Pragmatics in 1999, which gave a detailed and comprehensive explanation about the Adaptation Theory. This theory holds the view that the process of language using is a process of language choosing and adapting. Jef Verschueren defined pragmatics as "a general cognitive, 
social, and cultural perspective on linguistics phenomena in relation to their usage in forms of behavior" (Verschueren, 2000, p. 7).

According to Verschueren (2000), "using language must consist of the continuous making of linguistic choices, consciously or unconsciously, for language-internal and/or language-external reasons" (p. 55). Three key notions - variability, negotiability, and adaptability, are the reasons why people make choices in language using process.

Variability is the property of language which defines the range of possibilities from which choices can be made. Negotiability is the property of language responsible for the fact that choices are not made mechanically or according to strict rules or fixed form-function relationships, but rather on the basis of highly flexible principles and strategies. Adaptability, then, is the property of language which enables human being to make negotiable linguistic choices from a variable range of possibilities in such a way as to approach points of satisfaction for communicative needs. (Verschueren, 2000, pp. 59-61).

Communicative context includes language users - utterer and interpreter, the mental world, the social world, and the physical world. Aspects of physical, social, and mental reality get activated by the utterer and the interpreter in their respective choice-making practices, and that is how they become part of the language use as elements with which the making of choices is interadaptable.

\section{Analysis on the Adaptability of Person Deixis in College English Teacher Talk}

\section{Adaptation to Emotive Elements}

Teacher talk is a crucial element in the classroom. In many EFL contexts, teacher talk represents the only "live" target language input that learners receive (Nunan \& Bailey, 2010). It is not unusual to get the following verbal expressions containing person deixis in teacher talk.

Example (6) $W e^{\prime} l l$ have an oral English test on Monday.

Example (7) We are students and study is still our main concern.

Example (8) A good command of the English language is like a pair of wings for us.

In the above examples, the first person plural "we", "our", and "us" all refer to the addressee "you", that is, the students, excluding the addresser. This kind of we-exclusive-of-addresser usage shows that the teacher takes students as pragmatic stance, trying to understand and feel from the angle of students. In this way, what is said by the teacher is more likely to be accepted by the students than in the way where "you" rather than the first person plural "we", "our", and "us" are employed. This process is called empathy, which means the process of "putting yourself into someone else's shoes" of reaching beyond the self and understanding and feeling what another person is understanding or feeling (Brown, 2002; Guiora, Brannon, \& Dull, 1972).

In Example (6), the teacher reminds the students of their coming test. Taking test is usually considered as some kind of pressure on students. That the teacher uses grammatically "we" to replace "you" in this case means that the teacher intends to shoulder the pressure of taking exam with students, thus releasing the pressure of the students to some extent, and establishing harmonious relationship with students.

In Example (7), the teacher gives his suggestions to the students. "We" actually refers to the addressee "you", the students. The purpose is that the teacher wants to preserve students" face, "their public self-image" (Verschueren, 2000, p. 45), thus reinforcing the persuasion effects. Using first person plural "we" rather than the 
second person plural "you" may shorten the distance between the addresser (the teacher) and the addressees (the students) so as to make suggestions more likely to be taken by the students. Schmitt (2008) thinks that "some individuals (and maybe some cultural groups) are more sensitive to face issues than others" (p. 89); therefore, in classroom setting, teachers need to be very sensitive to face issue in order to have a good rapport with students in the situations like giving feedback, making suggestions, criticizing a student in some way, or even just nominating someone to answer a question.

In Example (8), the teacher uses a metaphor "a pair of wings" to depict a glamorous picture to the students if they can master the English language. For " $u s$ " actually refers to for "you". Why does the teacher use " $u s$ " instead of "you"? Probably because the teacher intends to show students' mastering the English language is the common desire both for the teacher and for the students so as to motivate students to exert great efforts in English learning. If their strong motivation is stimulated and strengthened, surely we can imagine their success in a learning task.

From the above analysis, we can see that teachers using person deixis in their talk, consciously or unconsciously, adapts to emotive elements, like empathy, face and motivation, etc.

In the classroom communication, person deixis in teacher talk may possess important pragmatic functions such as empathizing, preserving students' face, and strengthening students' motivation, and the like.

\section{Adaptation to the Social Relations Between Teachers and Students}

Person deixis is not restricted to an identification of utterers and interpreters, also "others" (the third person) are focused on, a process which often involves foregrounding of properties which position people in a social world (Verschueren, 2000, p. 91). An important element of social world for human being is the social relationship. It takes place in a great quantity of contexts, such as family, marriage, neighborhoods, work, parties, and so on. The social relationship in teaching context is mainly among teachers and students. Teachers may regulate the social relations with students in many ways, one of which is using person deixis in their talk. For example:

Example (9) Teacher to students: We won't start until everyone is quiet.

In this example, students are talking before class starts. The teacher is trying to make students stop talking so as to start his lecture. The teacher may put it another way, i.e., "I'm waiting for you to be quiet and then I start my lecture". But why does the teacher not use "I" in the example, but use "we" instead? The possible answer could be that the teacher intends to let all students join him with his lecture. "We" here refers to not only the addresser "I", but also the addressees "you", the students. The purpose is to shorten the distance between the teacher and the students, and make students be involved in the class lecture voluntarily, thus establishing rapport with the students and fostering a pleasant and supportive classroom atmosphere.

\section{Adaptation to the Teachers' Roles}

In actual teaching settings, teachers are the most visible figures in the classroom, and their main role is to "facilitate the communication process between all participants in the classroom, and between these participants and the various activities and texts" (Breen \& Candlin, 1980, p. 99). Using person deixis properly is one of the most frequently adopted teaching strategies to function teachers' roles. For example:

Example (10) Teacher to students: We will continue our lesson from where we left off yesterday.

In this example, the teacher uses the first person plural "we", trying to get the students involved in the teaching activities by means of we-inclusive-of-addresser/addressee and conduct the teaching activity smoothly. 
By using " $w e$ ", the teacher wants to arouse students' sense of duty and establish close relations with them, thus taking his role of being a director, a guide, and an instructor and having an impact on the students' commitment to learning.

\section{Adaptation to Students' Physical Feedback}

Teacher talk and students' reactions are interactive and interconnected. Students' feedback is an important basis for teachers to adjust their teaching strategies. Apart from students' verbal feedback, students' physical feedback, such as paralanguage, body language, and facial expressions may determine certain linguistic choices in teacher talk.

For example, if the teacher finds that some students often scratch their heads or stare at him, he knows that they want to answer the question, but they are too shy to raise their hands and speak out the answers before the whole class. So he says to the students: "We know you have good ideas". The first person plural form "we" is used to give encouragements to those students who have shown their intention to answer the question.

\section{Conclusion}

In the communicative teaching context, the proper reference and exact meaning of person deixis in teacher talk must be interpreted and understood with the help of communicative contextual analysis. According to the adaptation theory, this paper explores the contextual adaptation of person deixis in English teacher talk. The utilization of person deixis is a dynamic process of making choices. It is found that person deixis adopted by teachers in the English language classroom plays an important role in empathizing, preserving students' face, strengthening students' motivation, and establishing harmonious teacher-student relationship, which may facilitate English teaching and produce better learning results effectively.

\section{References}

Breen, M., \& Candlin, C. (1980). The essentials of a communicative curriculum in language teaching. Applied Linguistics, 1(2). Brown, H. D. (2002). Principles of language learning and teaching. Beijing: Foreign Language Teaching and Research Press.

CHEN, X. R. (2009). A new coursebook in pragmatics. Beijing: Foreign Language Teaching and Research Press.

Fillmore, C. J. (1971). The Santa Cruz lectures on deixis. Bloomington, IN: Indiana University Linguistic Club.

Guiora, Z., Brannon, C., \& Dull, Y. (1972). Empathy and second language learning. Language Learning, 22, 111-130.

Huang, Y. (2009). Pragmatics. Beijing: Foreign Language Teaching and Research Press, Oxford University Press.

Levinson, S. C. (1983). Pragmatics. Cambridge: Cambridge University Press.

Lyons, J. ( 1977). Semantics (Vol. 2). Cambridge University Press.

Nunan, D., \& Bailey, K. (2010). Exploring second language classroom research: A comprehensive guide. Beijing: Foreign Language Teaching and Research Press, and Cengage Learning.

Schmitt, N. (2008). An introduction to applied linguistics. Beijing: World Publishing Corporation.

Verschueren, J. (2000). Understanding pragmatics. Beijing: Foreign Language Teaching and Research Press, Edward Arnold (Publishers) Limited. 